\title{
Effect of hook and bait type on catch per unit effort in the Aegean Sea demersal longline fishery
}

\section{Ege Denizi dip paragat balıkçılığında iğne ve yem tipinin birim çabada av miktarına etkisi}

\author{
Ozan Soykan ${ }^{1}$ - Cemil Sağlam²* • İlker Aydın ${ }^{3}$ • Hasan Tuncay Kınacıgil4 \\ 1 Ege University, Faculty of Fisheries, Bornova, İzmir, Turkey \\ ${ }^{2}$ Ordu University, Fatsa Faculty of Marine Sciences, Fatsa, Ordu, Turkey \\ ${ }^{3}$ Ege University, Faculty of Fisheries, Bornova, Izmir, Turkey \\ ${ }^{4}$ Ege University, Faculty of Fisheries, Bornova, Izmir, Turkey

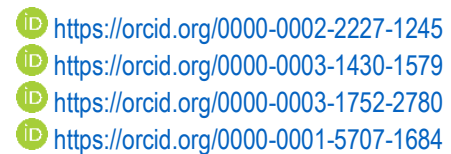

${ }^{*}$ Corresponding author: csaglam@odu.edu.tr

Received date: 13.08 .2020

Accepted date: 25.01 .2021

\author{
How to cite this paper: \\ Soykan, O., Sağlam, C., Aydın, I. \& Kınacıgil, H.T. (2021). Effect of hook and bait type on catch per unit effort in the Aegean Sea demersal longline fishery. \\ Ege Journal of Fisheries and Aquatic Sciences, 38(2), 181-188. DOI: 10.12714/egejfas.38.2.07
}

\begin{abstract}
This study aimed to determine the impact of hook and bait type on the catch composition and catch per unit effort. Effects of hook and bait types on catch composition, catch per unit effort (CPUE), length and weight distributions in demersal longline fishery were determined by experimental surveys on demersal longline sets in the Aegean Sea. A total of 12 samplings corresponding to 4800 hook fishing effort were performed between April 2014 and September 2014. Two bait types; sardine (Sardina pilchardus) and grooved razor shell (Solen marginatus) and two hook types; J-hook and C-hook were tested. CPUE values were calculated for each species and assessed between different hook-bait combinations.

A total of 623 individuals were captured belonging to 3 families and 9 species. It was found that more than $60 \%$ of total catch was captured by grooved razor shell and more than $50 \%$ of the total catch was caught with $\mathrm{J}$ type hook. $J$ hook was found to be close to significant $(p=0.06)$ and grooved razor shell was found significant $(\mathrm{p}=0.02)$ for CPUE. The effect of bait type was found to be more significant than that of hook type for CPUE and length distribution. Hookbait combination differed according to species and $\mathrm{C}$ hook baited with sardine was determined to be the best combination for Sparus aurata as the most targeted fish in the study area. Discard ratio was calculated to be $34 \%$ in terms of weight and $42.5 \%$ in terms of total number of individuals for pooled data. The condition value $(\mathrm{K})$ of the species ranged from 1.05 to 1.68 and differed according to bait type.

Most of the high commercial value species caught with any hook-bait combination experimented within this study are larger than minimum fishing length according to minimum landing size regulations of Turkish fishery and maturity studies.

Keywords: Demersal longline, hook style, bait type, CPUE

Öz: Bu çalışmada iğne ve yem türlerinin, avlanan balık av kompozisyonu ve birim çabada av miktarı (BÇAM) üzerindeki etkisinin belirlenmesi amaçlanmış̧ır. İğne ve yem türlerinin av miktarına, birim çabada av miktarına (BÇAM), boy ve ağırlık dağılımlarına etkisi, Ege Denizi'nde kullanılan deneysel dip paragatları ile saptanmıștır. Toplam 12 adet tekrar ile 4800 adet iğne kullanılarak Nisan 2014 ve Eylül 2014 ayları arasında örnekleme yapılmıştır. Iki yem tipi olarak Sardalya (Sardina pilchardus Walbaum, 1972) ve Sülünez (Solen marginatus Pulteney, 1799) ve iki iğne tipi olarak J-iğne ve C-iğne test edilmiştir. BÇAM her tür için ve farklı iğne-yem tiplerine göre hesaplanmıştır.

3 aileye ait farklı 9 türden 623 adet balık yakalanmıştır. Toplam avın \%60'ından fazlasının sülünez ve \%50'den fazlasının J tipi iğne ile yakalandığı bulunmuştur. BÇAM için J tipi iğne ile avcllık istatistiksel olarak önemli değere yakın $(p=0.06)$ ve sülünez ile avcllık istatistiksel olarak önemli $(p=0.02)$ bulunmuştur. Yem türünün BÇAM ve balık boyutu üzerindeki etkisi, iğne türünden daha önemli bulunmuştur. İğne-yem kombinasyonu türlere göre farklılık göstermektedir ve sardalya ile yemlenen C tipi iğne, calıșma alanında en cok hedeflenen balık olan Sparus aurata için en iyi kombinasyon olarak belirlenmiş̧tir. Toplanan veriler için ıskarta oranı ağırlığa göre \% 34.0 toplam tür sayısı açısından $\% 42.5$ olarak hesaplanmış̧ı. Türlerin kondüsyon değeri (K) 1.05 ile 1.68 arasında değişmekte ve yem türüne göre farklıık göstermektedir. Bu çalışmada kullanılan iğne-yem kombinasyonu ile yakalanmış yüksek ticari değeri bulunan türlerin çoğu, yasal avlanma boyu ve cinsi olgunluk çalışmalarına göre, minimum avlanma boyundan büyüktür.

Anahtar kelimeler: Dip paragatı, iğne tipi, yem tipi, BÇAM
\end{abstract}

\section{INTRODUCTION}

A longline is composed of the principal line along which, at various places snoods equipped with baited hooks are attached. This fishing apparatus can be compared to a series of lines placed at regular intervals and left in the water for a few hours. Longlining, as a traditional fishing method, is perhaps one of the most ancient as it was used from the shore. Depending on the species of fish being sought, the longline can be set at different depths; demersal, pelagic or mixed (FAO, 1993).
Longline fishing is considered to be more selective than other fishing gears like gillnets or trawls (Gilman et al., 2006), even so, both demersal and pelagic longline fisheries experience by-catch of important species such as marine mammals, sea birds, sea turtles and sharks (Gilman et al 2006, 2008; Lewison et al., 2004; Soykan et al., 2008). Because of that some studies have been done on the effects of bait types and hook styles in the commercial and recreational fisheries (Coelho et al., 2012; Foster et al., 2012; 
Santos et al., 2012, 2013; Fernandez-Carvalho et al., 2015; Amorim et al., 2015; Sistiga et al., 2018).

Longline fishery constitutes an important part of the Aegean and Mediterranean coasts of Turkish Seas. There have been 14479 commercial fishing vessels and 31842 fishing employees (fishermen) in Turkey and 3845 of those are longline vessels creating a population of 3714 fishermen in the field of longlining (Anonymous, 2017). Demersal longline fishery is an important fishing method for small-scale fishermen in Izmir Bay. Although there are some studies that have focused on different aspects of longline fishery for Turkey (Ulaş and Düzbastılar, 2001; Özyurt et al., 2003; Çekiç and Başusta, 2004, Erdem and Akyol, 2005; Özdemir et al., 2006; Akyol et al., 2007; Özgül et al., 2015; Gülşahin and Soykan, 2017; Güçlüsoy et al., 2020), information regarding the bait, hook size, catch composition, discard ratios and catch per unit effort (CPUE), are scarce and variable.

The aim of the present paper is to determine the hook and bait effects on the catch composition, length and weight distributions, catch per unit effort and discard ratios of demersal longline fishery.

\section{MATERIAL AND METHODS}

This study was carried out in Urla region located in the central Aegean Sea from a research boat named "Nereis" which belongs to Ege University Faculty of Fisheries during the period from April to September 2014 (Figure 1). Fishing trials were performed daily and 4 longline sets each including 100 hooks were used during operations. The experimental longline design consisted of two bait and two hook types in each longline set. Polyester material braided rope with a diameter of $0.45 \mathrm{~mm}$ was used as the main line, while the snoods were made of $0.30 \mathrm{~mm}$ diameter nylon monofilament. Traditional straight ( $\mathrm{J}$ style) hooks were used together with alternative circle ( $\mathrm{C}$ style) hooks on the experimental longline and hooks were prepared along the main line as one $\mathrm{J}$ hook and one $\mathrm{C}$ hook one after the other $(\mathrm{J}, \mathrm{C}, \mathrm{J}, \mathrm{C}, \ldots)$.

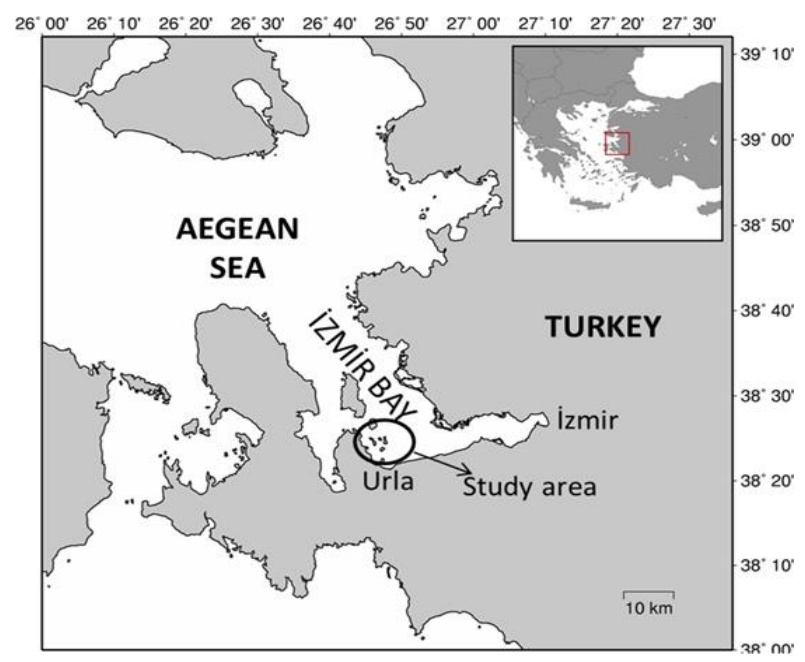

Figure 1. Study area
J style hook (Model: Owner 50560 Furansu, Figure 2) is being used traditionally in the Aegean Sea by small-scale fishermen in longline fishery and angling. $C$ style hook (Model: Owner 50660 Mutu, Figure 2) was used alternatively in order to compare the efficiency of hook styles. Baits were sardine (Sardina pilchardus) and grooved razor shell (Solen marginatus) and they were placed alternately on each hook type. Only one bait type was used in each set-in order to avoid possible interaction effects as suggested by Watson et al. (2005). Bait pieces were standardized to $3 \mathrm{~cm}$ long in order to avoid the effect of bait size on fish length (Soykan et al., 2016). Point, barb and the bend of the hooks were totally covered with bait. Totally 4800 hooks were examined corresponding to 1200 hook/bait combinations. The period of fishing operations was set to noon to 2 hours between $5-20 \mathrm{~m}$ depths.

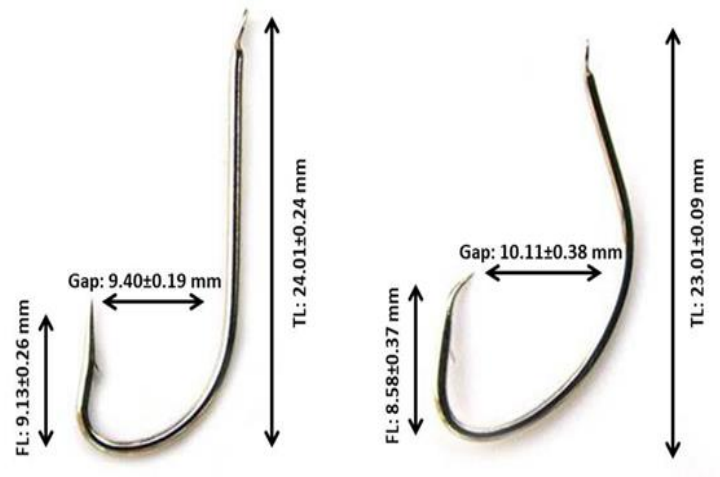

Figure 2. Hook styles and their measurements with standard deviation ( $\mathrm{TL}=$ Total length, $\mathrm{FL}=$ Front length)

Captured specimens were brought to the laboratory and total length $(\mathrm{TL})$ was measured in the natural body position to the nearest $\mathrm{mm}$. Total weight $(\mathrm{W})$ was measured to the nearest $0.1 \mathrm{~g}$. Information such as geographical position, date, timing was recorded for each longline operation.

Catch per unit effort (CPUE) value was calculated in weight (g) per 100 hooks for each species in each fishing set (including sets with zero catches for those particular species) and the mean CPUE with the respective standard deviations for each hook-bait combination was calculated. CPUE data was tested for normality with Kolmogorov-Smirnov tests with Lilliefors correction (Lilliefors, 1969) and for homoscedasticity with Levene's tests. Normality and homoscedasticity assumptions were violated, so non-parametric test (MannWhitney) was employed to test for differences among the two baits and two hook types.

The size distribution of species and condition factor were compared according to different hook styles and bait types. The skewness and the kurtosis of the size data were calculated to assess departures from normality, and the results indicated that parametric tests were not appropriate to compare mean sizes among treatments, so for each hook-bait 
combination, the mean size and the mean condition factor and its respective standard deviation were calculated and Mann-Whitney $U$ test was used to compare the sizes between hooks styles and between bait types.

Fulton's condition factor:

$$
\mathrm{K}=\left(\mathrm{W} \mathrm{L}^{-3}\right) 100
$$

where $W$, the weight and $L$, total length of the fish, was also used to calculate $\mathrm{K}$ (condition) of each fish.

Length-weight relationship (LWR) was calculated for all species. Parameters of LWR for six fish species were estimated by logarithmic transformation: $\log W=\log a+b \log$ $L$ with $a$ and $b$ determined via least-squares regression.

Discard ratio (dr) was calculated with the formula given below (Kelleher, 2005):

$$
\mathrm{Dr}=\left(\text { Discards } \mathrm{x} \text { Total } \text { catch }^{-1}\right) 100
$$

Accuracy of the growth parameters was examined by the $\mathrm{t}$-test and the statistical analyses were performed using the $\mathrm{R}$ project for Statistical Computing Version 3.4.2 (R Core Team, 2017).

\section{RESULTS}

Longline operations resulted in 9 species belonging to 3 families. A total of 623 individuals corresponding to $36.8 \mathrm{~kg}$ were sampled and $58.1 \%$ belonged to sparids, $40.6 \%$ to serranids. D. annularis dominated the catch composition in terms of number with $28.2 \%$ and followed by $S$. cabrilla $(27.6 \%)$ and $B$. boops (15.9\%). G. niger was represented with the least number of individual (1.3\%). Three species, $S$. aurata, $D$. annularis and $B$. boops composed more than the half of the total catch in terms of weight with $24 \%, 17 \%, 12 \%$ respectively. The contribution of the other sparid species, $P$. erythrinus, $L$. mormyrus and $D$. vulgaris on the total catch weight was calculated to be $8 \%, 5 \%$ and $1 \%$ respectively. Representatives of the family serranidae composed almost $1 / 3$ of total catch in weight and S. cabrilla and S. scriba had each $16 \%$ ratio within the total catch. G. niger represented $1 \%$ of the total weight.

While $39.4 \%$ of the total catch in terms of weight was captured by sardines, $60.6 \%$ was obtained by grooved razor shell. On the other hand, according to number-based distribution, $32.1 \%$ of the total catch belonged to sardine and the rest $(67.9 \%)$ to grooved razor shell. $44.7 \%$ of the total catch weight was performed by $\mathrm{C}$ hook and $55.3 \%$ by $\mathrm{J}$ hook. Regarding the number-based distribution of the whole catch, 43.3\% was done with $\mathrm{C}$ hook and $56.7 \%$ with J hook.

Discard ratio was calculated to be $34 \%$ in terms of weight and $\% 42.5$ in terms of total number of individuals for pooled data. Moreover, weight-based discard ratio of $C$ hook baited with sardine and with grooved razor shell were calculated to be $4.22 \%$ and $10.85 \%$, J hook baited with sardine and with grooved razor shell were $5.84 \%$ and $11.75 \%$ respectively. Discard ratios in terms of number of captured fish according to hook and bait type also differed. $C$ hook baited with sardine and with grooved razor shell were found to be $6.26 \%$ and $12.36 \%$, J hook baited with sardine and with grooved razor shell were calculated as $6.58 \%$ and $17.34 \%$ respectively.

The $a$ and $b$ parameters of the LWR are presented in Table 1. The $b$ values varied from 2.40 (B. boops) to 3.31 ( $G$. niger). Isometric growth was observed for $D$. annularis, $P$. erythrinus, D. vulgaris. Species with positive allometric growth were $S$. cabrilla, G. niger and negative allometric growth was observed for B. boops, S. aurata, L. mormyrus, S. scriba.

Table 1. Length-weight relationship parameters $(95 \% \mathrm{Cl}$ ), descriptive statistics (mean, min-max, standart error) and fish status (C: commercial, NC: noncommercial) ( ${ }^{*}$ Length-weight relationship parameters $a$ and $b$ range of min-max for 9 species of Fishbase data

\begin{tabular}{|c|c|c|c|c|c|c|c|c|c|}
\hline & $\mathrm{n}$ & $a$ & b & $\mathbf{R}^{2}$ & Length & Weight & Status & $a^{*}$ & $\mathbf{b}^{*}$ \\
\hline SPARIDAE & & & & & & & & & \\
\hline $\begin{array}{l}\text { Diplodus annularis } \\
\text { (Linnaeus, 1758) }\end{array}$ & 176 & $\begin{array}{l}0.0130 \\
(0.0097-0.0174)\end{array}$ & $\begin{array}{l}3.09 \\
(2.98-3.21)\end{array}$ & 0.94 & $\begin{array}{l}12.6 \pm 0.13 \\
(9.7-18.8)\end{array}$ & $\begin{array}{l}35.1 \pm 1.21 \\
(15.9-100.0)\end{array}$ & $\mathrm{NC}$ & $0.004-0.080$ & $2.68-3.95$ \\
\hline $\begin{array}{l}\text { Boops boops } \\
\text { (Linnaeus, 1758) }\end{array}$ & 99 & $\begin{array}{l}0.0589 \\
(0.0444-0.0780)\end{array}$ & $\begin{array}{l}2.40 \\
(2.30-2.50)\end{array}$ & 0.96 & $\begin{array}{l}16.3 \pm 0.24 \\
(12.1-20.5)\end{array}$ & $\begin{array}{l}49.4 \pm 1.68 \\
(22.0-85.00)\end{array}$ & C & $0.002-0.17$ & $2.81-3.52$ \\
\hline $\begin{array}{l}\text { Sparus aurata } \\
\text { (Linnaeus, 1758) }\end{array}$ & 41 & $\begin{array}{l}0.0250 \\
(0.0203-0.0307)\end{array}$ & $\begin{array}{l}2.78 \\
(2.72-2.84)\end{array}$ & 0.99 & $\begin{array}{l}26.5 \pm 0.89 \\
(18.7-36.0)\end{array}$ & $\begin{array}{l}253.6 \pm 23.61 \\
(87.2-570.0)\end{array}$ & C & $0.006-0.027$ & $2.74-3.34$ \\
\hline $\begin{array}{l}\text { Pagellus erythrinus } \\
\text { (Linnaeus, 1758) }\end{array}$ & 28 & $\begin{array}{l}0.0118 \\
(0.0060-0.0231)\end{array}$ & $\begin{array}{l}3.05 \\
(2.81-3.30)\end{array}$ & 0.96 & $\begin{array}{l}15.5 \pm 0.28 \\
(13.5-18.5)\end{array}$ & $\begin{array}{l}52.5 \pm 2.92 \\
(32.6-85.9)\end{array}$ & C & $0.011-0.099$ & $2.43-3.12$ \\
\hline $\begin{array}{l}\text { Lithognathus mormyrus } \\
\text { (Linnaeus, 1758) }\end{array}$ & 12 & $\begin{array}{l}0.0588 \\
(0.0175-0.1975)\end{array}$ & $\begin{array}{l}2.51 \\
(2.11-2.91)\end{array}$ & 0.95 & $\begin{array}{l}21.1 \pm 0.79 \\
(17.0-25.4)\end{array}$ & $\begin{array}{l}127.0 \pm 12.4 \\
(72.0-200.0)\end{array}$ & C & $0.006-0.026$ & $2.47-3.45$ \\
\hline $\begin{array}{l}\text { Diplodus vulgaris } \\
\text { (GeoffroySaint-Hilaire, 1817) } \\
\text { SERRANIDAE }\end{array}$ & 6 & $\begin{array}{l}0.0375 \\
(0.0134-0.1052)\end{array}$ & $\begin{array}{l}2.66 \\
(2.30-3.03)\end{array}$ & 0.99 & $\begin{array}{l}17.3 \pm 0.36 \\
(16.0-18.2)\end{array}$ & $\begin{array}{l}74.3 \pm 4.07 \\
(60.7-86.9)\end{array}$ & C & $0.003-0.086$ & $2.43-3.59$ \\
\hline $\begin{array}{l}\text { Serranus scriba } \\
\text { (Linnaeus, } 1758 \text { ) }\end{array}$ & 172 & $\begin{array}{l}0.0263 \\
(0.0210-0.0329)\end{array}$ & $\begin{array}{l}2.74 \\
(2.65-2.82)\end{array}$ & 0.96 & $\begin{array}{l}13.6 \pm 0.18 \\
(9.0-17.7)\end{array}$ & $\begin{array}{l}35.3 \pm 1.23 \\
(10.4-66.2)\end{array}$ & C & $0.004-0.030$ & $2.72-3.41$ \\
\hline $\begin{array}{l}\text { Serranus cabrilla } \\
\text { (Linnaeus, 1758) } \\
\text { GOBIIDAE }\end{array}$ & 81 & $\begin{array}{l}0.0088 \\
(0.0063-0.0124)\end{array}$ & $\begin{array}{l}3.18 \\
(3.06-3.30)\end{array}$ & 0.97 & $\begin{array}{l}16.1 \pm 0.35 \\
(12.4-22.8)\end{array}$ & $\begin{array}{l}69.4 \pm 5.06 \\
(26.00-191.00)\end{array}$ & NC & $0.009-0.073$ & $2.41-3.22$ \\
\hline $\begin{array}{l}\text { Gobius niger } \\
\text { (Linnaeus, 1758) }\end{array}$ & 8 & $\begin{array}{l}0.0072 \\
(0.0038-0.0136)\end{array}$ & $\begin{array}{l}3.31 \\
(3.05-3.56)\end{array}$ & 0.99 & $\begin{array}{l}11.9 \pm 0.69 \\
(9.7-14.7)\end{array}$ & $\begin{array}{l}28.4 \pm 5.09 \\
(12.50-51.00)\end{array}$ & $\mathrm{NC}$ & $0.005-0.017$ & $2.84-3.39$ \\
\hline
\end{tabular}
in Mediterranean Sea (Froese and Pauly, 2018)) 
Effects of the hook and bait type on the catch rates were assessed for each species. While the effect of bait was found to be significant for five species ( $P$. erthtinus, $L$. mormyrus, $B$. boops, $S$. scriba, $D$. vulgaris) the effect of hook was differed significantly for only two species ( $D$. annularis, $S$. cabrilla). Hooks baited with grooved razor shell had significantly higher CPUE than hooks baited with sardine for three commercial species $P$. erythrinus, $L$. mormyrus, $D$. vulgaris (Table 2). The catch of Serranus cabrilla had significantly higher CPUE values when using $\mathrm{J}$ hook in comparison to $\mathrm{C}$ hook. On the contrary, CPUE value of $D$. annularis differed significantly in favour of $C$ hook. $B$. boops and $S$. scriba had significantly higher CPUE values with sardine than that of grooved razor shell (Figure 3, Table 2).
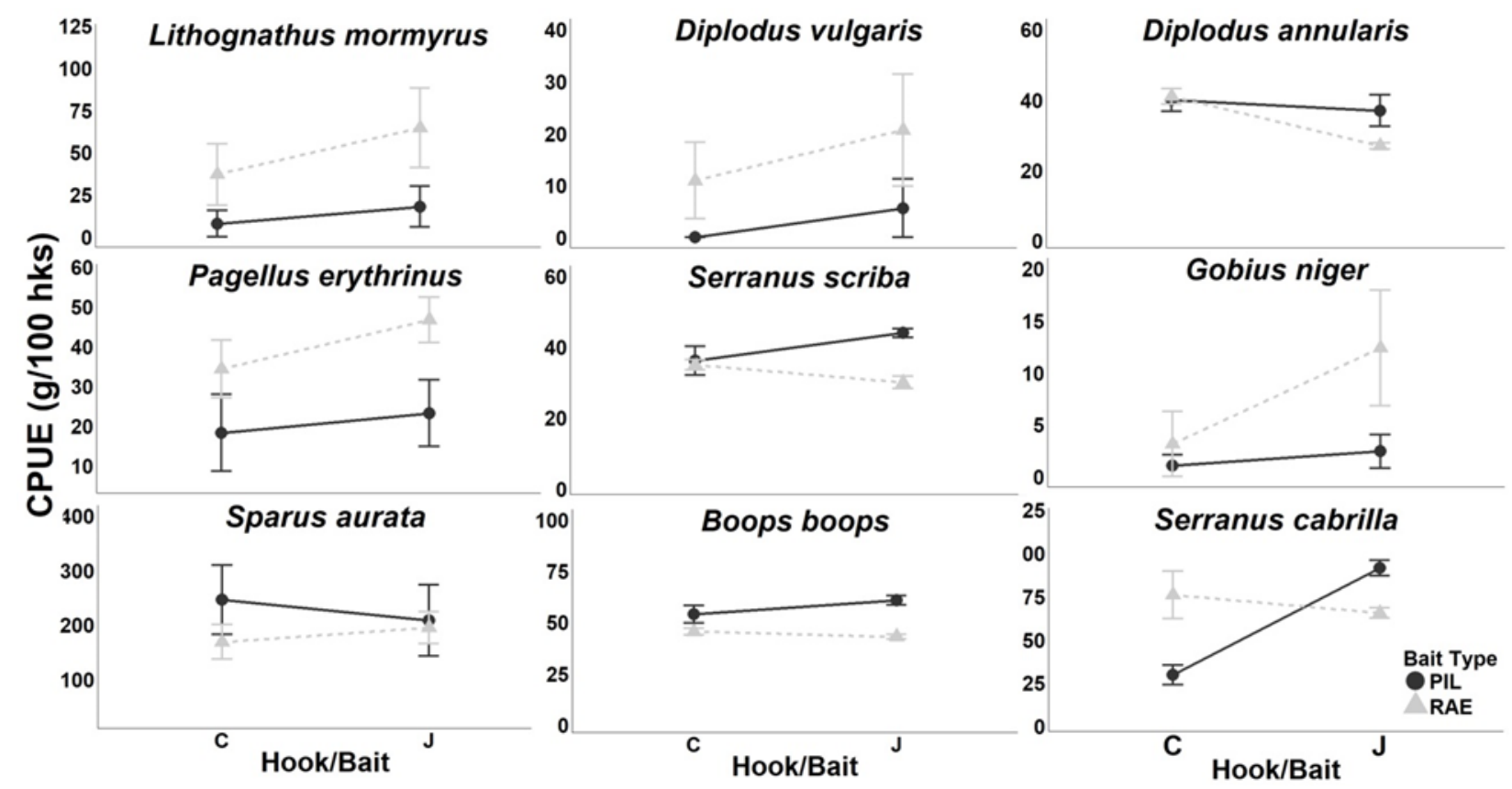

Figure 3. Catch per unit effort (CPUE, g/100 hooks) for target, bycatch and discard species. FAO codes for Sardina pilchardus (PIL) and Solen marginatus (RAE). Points refer to the means and error bars refer to the standard errors

Table 2. Mean CPUE ( $\mathrm{g} / 100$ hooks) with respective standard deviation between parentheses, for the various hook-bait combinations. $\mathrm{p}$ Values from non-parametric tests refer to Mann-Whitney U tests to compare bait types and hook styles ( ${ }^{*}$ sig. at the $10 \%$ level; ** sig. at the $5 \%$ level; ${ }^{* * *}$ sig. at the $1 \%$ level)

\begin{tabular}{|c|c|c|c|c|c|c|}
\hline \multirow{2}{*}{$\begin{array}{l}\text { Species } \\
\text { (n) }\end{array}$} & \multicolumn{2}{|c|}{ Sardina pilchardus } & \multicolumn{2}{|c|}{ Solen marginatus } & \multirow{2}{*}{ Bait } & \multirow{2}{*}{ Hook } \\
\hline & $\mathrm{J}$ & C & $\mathrm{J}$ & C & & \\
\hline Sparus aurata & $\begin{array}{l}207.6 \pm 225.9 \\
(7)\end{array}$ & $\begin{array}{l}245.7 \pm 218.9 \\
\text { (8) }\end{array}$ & $\begin{array}{l}195.1 \pm 100.9 \\
15\end{array}$ & $\begin{array}{l}168.8 \pm 109.8 \\
\text { (11) }\end{array}$ & 0.85 & 1.00 \\
\hline Pagellus erythrinus & $\begin{array}{l}23.2 \pm 28.9 \\
(5)\end{array}$ & $\begin{array}{l}18.3 \pm 33.4 \\
\text { (3) }\end{array}$ & $\begin{array}{l}46.7 \pm 19.9 \\
(11)\end{array}$ & $\begin{array}{l}34.3 \pm 25.2 \\
\text { (9) }\end{array}$ & $0.03^{* *}$ & 0.21 \\
\hline Lithognathus mormyrus & $\begin{array}{l}17.8 \pm 41.7 \\
(2)\end{array}$ & $\begin{array}{l}7.8 \pm 26.8 \\
\text { (1) }\end{array}$ & $\begin{array}{l}64.5 \pm 81.2 \\
\text { (5) }\end{array}$ & $\begin{array}{l}36.9 \pm 62.9 \\
\text { (4) }\end{array}$ & $0.04^{* *}$ & 0.36 \\
\hline Diplodus annularis & $\begin{array}{l}36.9 \pm 15.5 \\
(27)\end{array}$ & $\begin{array}{l}39.9 \pm 11.0 \\
(29)\end{array}$ & $\begin{array}{l}26.9 \pm 3.0 \\
(68)\end{array}$ & $\begin{array}{l}41.0 \pm 7.7 \\
(52)\end{array}$ & 0.24 & $<0.01^{*+*}$ \\
\hline Boops boops & $\begin{array}{l}60.6 \pm 7.9 \\
(25)\end{array}$ & $\begin{array}{l}53.8 \pm 14.6 \\
(12)\end{array}$ & $\begin{array}{l}42.9 \pm 4.0 \\
(31)\end{array}$ & $\begin{array}{l}45.7 \pm 5.7 \\
(31)\end{array}$ & $<0.01^{* *+*}$ & 0.58 \\
\hline Serranus scriba & $\begin{array}{l}43.9 \pm 4.3 \\
(37)\end{array}$ & $\begin{array}{l}36.014 .1 \\
(19)\end{array}$ & $\begin{array}{l}29.9 \pm 6.1 \\
(62)\end{array}$ & $\begin{array}{l}35.0 \pm 5.1 \\
(54)\end{array}$ & $<0.01^{* * *+}$ & 0.46 \\
\hline Serranus cabrilla & $\begin{array}{l}91.4 \pm 15.6 \\
(12)\end{array}$ & $\begin{array}{l}29.6 \pm 19.5 \\
(9)\end{array}$ & $\begin{array}{l}65.3 \pm 10.2 \\
(36)\end{array}$ & $\begin{array}{l}75.8 \pm 47.3 \\
(24)\end{array}$ & 0.59 & $<0.01^{*+*}$ \\
\hline Diplodus vulgaris & $\begin{array}{l}5.6 \pm 19.4 \\
(1)\end{array}$ & 0 & $\begin{array}{l}20.6 \pm 37.4 \\
(3)\end{array}$ & $\begin{array}{l}10.9 \pm 25.5 \\
\text { (2) }\end{array}$ & $0.08^{*}$ & 0.34 \\
\hline Gobius niger & $\begin{array}{l}2.4 \pm 5.6 \\
(2)\end{array}$ & $\begin{array}{l}1.0 \pm 3.6 \\
(1)\end{array}$ & $\begin{array}{l}12.4 \pm 19.3 \\
\text { (4) }\end{array}$ & $\begin{array}{l}3.1 \pm 10.8 \\
\text { (1) }\end{array}$ & 0.33 & 0.12 \\
\hline Total & $54.4 \pm 96.3$ & $48.0 \pm 102.2$ & $56.0 \pm 68.6$ & $50.1 \pm 64.7$ & $0.02^{* *}$ & $0.06^{*}$ \\
\hline
\end{tabular}


Effect of hook and bait type on fish size were determined. While the bait effect was found to be statistically significant for 6 species (S. aurata, P. erythrinus, D. annularis, B. boops, $S$. scriba, G. niger), hook effect was found to be distinctive for two species (D. annularis, S. cabrilla) (Table 3). Examination of hook type differences showed that the mean size of $D$. annularis caught with $C$ hook was found to be slightly higher than that of J hook. In contrast, S. cabrilla captured by J hook were bigger than that of $\mathrm{C}$ hook. According to bait types, average size of fish captured by $S$. pilchardus were significantly higher for $S$. aurata, $P$. erythrinus, $D$. annularis, $B$. boops, S. scriba than grooved razor shell did. Hook and bait types were determined to be non-effective for $L$. mormyrus (Table 3). Maximum number of individuals for each species was captured by $\mathrm{J}$ hook-grooved razor shell combination.

Table 3. Mean sizes with the respective standard deviation (between parentheses) p-values refer to the Mann-Whitney tests to compare sizes with different baits and with different hooks $\left({ }^{*}\right.$ sig. at the $10 \%$ level; ${ }^{* *}$ sig. at the $5 \%$ level; ${ }^{* * *}$ sig. at the $1 \%$ level)

\begin{tabular}{|c|c|c|c|c|c|c|}
\hline & \multicolumn{2}{|c|}{ Hook style } & \multicolumn{2}{|c|}{ Bait type } & \multirow{2}{*}{ Bait } & \multirow{2}{*}{ Hook } \\
\hline & $J$ & C & Solen marginatus & Sardina pilchardus & & \\
\hline Sparus aurata & $26.3 \pm 5.8$ & $26.7 \pm 5.8$ & $24.3 \pm 4.4$ & $30.4 \pm 5.7$ & $<0.01^{\text {t*k }}$ & 0.81 \\
\hline Pagellus erythrinus & $15.6 \pm 1.1$ & $15.4 \pm 1.9$ & $15.1 \pm 1.4$ & $16.5 \pm 1.2$ & $0.02^{* *}$ & 0.45 \\
\hline Lithognathus mormyrus & $22.3 \pm 1.4$ & $19.5 \pm 3.4$ & $21.4 \pm 3.1$ & $20.2 \pm 0.8$ & 0.48 & 0.11 \\
\hline Diplodus annularis & $12.0 \pm 1.5$ & $13.3 \pm 1.7$ & $12.4 \pm 1.6$ & $13.0 \pm 1.8$ & $0.04^{* *}$ & $<0.01^{* \star *}$ \\
\hline Boops boops & $16.5 \pm 2.3$ & $16.0 \pm 2.5$ & $15.5 \pm 2.3$ & $17.7 \pm 1.8$ & $<0.01^{* * *}$ & 0.61 \\
\hline Serranus scriba & $13.5 \pm 2.5$ & $13.7 \pm 2.2$ & $13.1 \pm 2.4$ & $14.6 \pm 1.9$ & $<0.01^{*+* *}$ & 0.52 \\
\hline Serranus cabrilla & $16.5 \pm 2.6$ & $15.5 \pm 3.7$ & $16.1 \pm 3.4$ & $16.1 \pm 2.3$ & 0.61 & $0.03^{* *}$ \\
\hline Diplodus vulgaris & $17.6 \pm 0.7$ & $16.5 \pm 0.7$ & $17.4 \pm 1.0$ & $16.6 \pm 0.0$ & 0.66 & 0.26 \\
\hline Gobius niger & $12.1 \pm 2.0$ & $11.6 \pm 2.5$ & $13.2 \pm 1.2$ & $9.9 \pm 0.2$ & $0.04^{* *}$ & 0.85 \\
\hline
\end{tabular}

The condition value $(K)$ of the species ranged from 1.05 to 1.68. It was considered that that hooks baited with grooved razor shell were more attractive for higher conditioned specimens of $B$. boops $(p<0.01)$ and $S$. aurata $(p<0.05)$. On the contrary, sardine bait was found to be more efficient for specimens of $S$. cabrilla which have higher conditions (Table 4).
L. mormyrus was the only species with a statistical difference on condition factor between the hook types. It can be declared that individuals in better conditions were captured by $C$ type hook for this species. Consideration of bait types showed that better conditioned individuals of $B$. boops $S$. aurata and G. niger were captured by $S$. marginatus. Better conditioned specimen of $S$. cabrilla were caught by the bait $S$. pilchardus (Table 4).

Table 4. Condition factor of the species with the respective standard deviation (between parentheses) $p$-values refer to the Mann-Whitney tests to compare sizes with different baits and compare sizes with different hooks ( ${ }^{*}$ sig. at the $10 \%$ level; ${ }^{* *}$ sig. at the $5 \%$ level; ${ }^{* * *}$ sig. at the $1 \%$ level)

\begin{tabular}{lcccccc}
\hline & \multicolumn{2}{c}{ Hook style } & \multicolumn{2}{c}{ Bait type } & \multirow{2}{*}{ Bait } & Hook \\
\hline Serranus cabrilla & $\mathrm{J}$ & $\mathrm{C}$ & Solen marginatus & Sardina pilchardus & & \\
Serranus scriba & $1.48 \pm 0.14$ & $1.45 \pm 0.18$ & $1.39 \pm 0.13$ & $1.56 \pm 0.23$ & $0.00^{* * *}$ & 0.28 \\
Diplodus annularis & $1.35 \pm 0.19$ & $1.30 \pm 0.11$ & $1.33 \pm 0.17$ & $1.29 \pm 0.10$ & 0.21 & 0.11 \\
Boops boops & $1.63 \pm 0.15$ & $1.67 \pm 0.18$ & $1.64 \pm 0.17$ & $1.68 \pm 0.17$ & 0.14 & 0.24 \\
Sparus aurata & $1.10 \pm 0.14$ & $1.13 \pm 0.14$ & $1.15 \pm 0.14$ & $1.05 \pm 0.10$ & $0.00^{* * *}$ & 0.31 \\
Pagellus erythrinus & $1.22 \pm 0.08$ & $1.24 \pm 0.06$ & $1.24 \pm 0.07$ & $1.21 \pm 0.08$ & $0.03^{* *}$ & 0.59 \\
Lithognathus mormyrus & $1.36 \pm 0.08$ & $1.37 \pm 0.07$ & $1.36 \pm 0.08$ & $1.38 \pm 0.06$ & 0.82 & 0.98 \\
Diplodus vulgaris & $1.26 \pm 0.08$ & $1.40 \pm 0.16$ & $1.34 \pm 0.15$ & $1.25 \pm 0.03$ & 0.58 & $0.07^{*}$ \\
Gobius niger & $1.43 \pm 0.03$ & $1.45 \pm 0.04$ & $1.43 \pm 0.03$ & $1.47 \pm 0.00$ & 0.67 & 0.80 \\
\hline
\end{tabular}

\section{DISCUSSION}

Longline fishery has an important role in the small-scale fishery of the Aegean Sea. The main reason for this importance is low of fishing expenditures generally brings commercially valuable species. Moreover, small-scale fishermen and recreational anglers are using similar hook and bait types in longline and handline fisheries. For this reason, studies regarding the hook styles and bait types are important for both recreational and commercial fishermen. Although some studies were carried out on hook and bait types, commercial and discard ratios of longline fishery and length- 
weight relationships of captured specimen in the study area, our paper covers the assessment of these parameters together for the first time.

When we examined CPUE with hook type, no significance was found for commercial species, but significant effect was detected for two discard species, $D$. annularis and $S$. cabrilla. CPUE value of $C$ hook was slightly higher for $D$. annularis, conversely it was lower for $S$. cabrilla. which was reported as a discard species in many studies (Akyol, 2003; Aydın et al, 2008; Gökçe and Metin, 2007). On the other hand, Gülşahin and Soykan (2017) reported this species to be commercial in the South Aegean Sea. The reason for this case is attributable to dynamic structure of the word "discard" as it is affected by many factors and probably the most important ones are "regionality" and "consumer's preference". Total CPUE result showed that $\mathrm{J}$ hook has slightly higher than $\mathrm{C}$ hook for CPUEs. So, J hook is suggested for fishermen regardless of the quality of the catch. Beside the hook type, significant influence of hook size on the body size was also emphasized for white seabream and gilthead sea bream in Foça (Güçlüsoy et al., 2020).

Grooved razor shell and sardine are two of the most popular and cheap baits for commercial and recreational fishermen on the Turkish coast of the Aegean Sea. That's why scientific literature on the bait type of longline fishery in the study area was accumulated for the grooved razor and sardine. Özdemir et al (2006) used different bait types, squid (Loligo vulgaris) and sardine in Urla region and they caught $22 \%$ of the hall catch with sardine in demersal longline. Soykan et al (2016) reported that more than half of the catch by sardine (32\%) and grooved razor (23\%) in Urla and Çeşme region. Maktay (2012) examined the effects of deep water rose shrimp (Parapenaeus longirostris) and sardine as baits on the catch composition of longlining in Urla and reported the dominance of sardine with $77.4 \%$. Çekiç and Başusta (2004) revealed that $55.3 \%$ of the total catch was captured by sardine and the rest by common cuttlefish (Sepia officinalis) in İskenderun Bay. In this study we found that catch amount for grooved razor shell was higher than that of sardine. Bait types were found significantly different for commercial species CPUEs, except $S$. aurata. CPUEs of grooved razor shell was slightly higher for $P$. erythrinus, $L$. mormyrus and $D$. vulgaris and CPUEs of sardine was slightly higher for $B$. boops, $S$. scriba. It was also observed that, commercial value of fish captured by grooved razor shell were higher than that of those captured with sardine depending on fish market prices in the region. Comparison of total CPUEs of the baits showed that grooved razor shell had significantly higher fishing effect. Therefore, grooved razor shell may be a better recommendation than sardine during bait choice in the study area.

It was determined that, hook type did not affect the condition of the captured individuals. On the other hand, bait was found to be significant for two commercial (B. boops, $S$. aurata) and two discard (S. cabrilla, G. niger) species. Aydın
(2011), reported condition factor values of $B$. boops and $D$. annularis captured by sardine and razor shell to be $1.18 \pm 0.13,1.07 \pm 0.09$ and $1.53 \pm 0.07,1.72 \pm 0.14$ respectively in the same area. On the contrary, in this study, condition factor of $B$. boops captured by razor shell was greater than Aydın's (2011) result. The difference is attributable to sampling technique. This may lead to make a further consideration that different fishing gears may have different effects on condition of the same species. In addition, while bigger individuals of $S$. aurata and $B$. boops were captured with sardine bait, more conditioned individuals of the same species were caught with grooved razor shell. This case showed that bait choice could differ between different size individuals of the same species. It was also reported that many factors affect the condition of fish such as sex and reproduction period, water temperature and salinity, sex and food availability (Aydın, 2011; Tesch, 1971; Moutopoulos and Stergiou, 2002)

Among the species composition of the study, S. aurata, $P$. erythrinus, L. mormyrus, B. boops, $D$. vulgaris, and S. scriba are of commercial importance in the Aegean Sea longline fishery. In this study discarded catch composition composed of 3 species ( $D$. annularis, S. cabrilla, G. niger) and numberbased discard ratio was $42.5 \%$. Discard ratios of the previous studies (Özdemir et al., 2006; Maktay, 2012; Odabaşı, 2013; Aydın and Bolat, 2014; Soykan et al., 2016; Gülşahin and Soykan, 2017) performed in Turkish coast of Aegean Sea ranged from $6.5 \%$ to $55.5 \%$ and our result is between the limits. The reason for this big range is due to quality and quantity of discards in longline fishery depends on several factors such as region, technical features of the gear, bait type and target species (Gülşahin and Soykan, 2017).

The relation between length and weight is an informative instrument in fisheries science. However, parameters of the length-weight relationship, even for the same species, differ between regions, sampling methods and the measurement accuracy of the researchers (Gülşahin and Soykan, 2017). When we compare our results on length-weight relationship parameters with those of other studies conducted in the Mediterranean basin; " $b$ " values are within the general range except for $B$. boops $(b=2.40)$ which is lower than other studies. Furthermore "a" value is also within the general range except for L. mormyrus (higher than compared studies) and S. cabrilla (slightly lower than previous studies) (Table 4). Various factors may be responsible for the differences on LWR parameters between seasons and years, such as temperature, salinity, food (quantity, quality, and size), sex, time of year and stage of maturity (Dulcic and Kraljevic, 1996). Also bait type affects the LWR in the longline fishery as the juvenile and mature individuals of the same species may have different feeding preferences (Gülşahin and Soykan, 2017).

Among 9 species obtained from the present study, only 3 of them were emphasized in the minimum landing size (MLS) regulation of the Turkish fishery legislation. While the total 
length of $S$. aurata was found to be higher for any hook-bait combination than $20 \mathrm{~cm}$ (Anonymous, 2016) and $P$. erythrinus was found to be higher for any hook-bait combination than 15 $\mathrm{cm}$ (Anonymous, 2016) given limit for Turkey, size of $D$. vulgaris for all hook-bait combinations was below $18 \mathrm{~cm}$ (Anonymous, 2016) MLS regulation. Therefore, hook style, bait type and their combination mentioned in this work is considered to be convenient for sustainable fishery of $S$. aurata and $P$. erythrinus. Absence of MLS regulation in Turkish fishery for other sparid and serranid species of the present study prevents making a comprehensive evaluation on the sustainability for those 6 species. However, we determined the length range of $P$. erythrinus in between 13.5 and $18.5 \mathrm{~cm}$ with a mean length of $15.5 \mathrm{~cm}$. Metin et al (2011) reported the length at maturity of females and males of $P$. erythrinus as 11.30 and $15.08 \mathrm{~cm}$, respectively. It was found higher than that of Metin et al (2011) indicating a sustainable fishing trend for the species. Soykan et al (2015), stated the length at maturity of $B$. boops (P) to be $12.96 \mathrm{~cm}$. In this study, it was found $16.3 \mathrm{~cm}$ for $B$. boops that is greater than the reported maturity length, which supports the sustainable fishery for the species.

\section{REFERENCES}

Akyol, O. (2003). Retained and trash fish catches of beach-seining in the Aegean coast of Turkey. Turk Journal of Veterinary and Animal Sciences, 27, 1111-1117.

Akyol, O., Kınacıgil, H.T. \& Şevik, R. (2007). Longline fishery and lengthweight relationships for selected fish species in Gökova Bay (Aegean Sea, Turkey). International Journal of Natural and Engineering Sciences, 1,1-4.

Amorim, S., Santos, M., Coelho, R. \& Fernandez-Carvalho, J. (2015). Effects of $17 / 0$ circle hooks and bait on fish catches in a southern Atlantic swordfish longline fishery. Aquatic Conservation: Marine and Freshwater Ecosystems, 25(4), 518-533, DOI: 10.1002/aqc.2443

Anonymous (2016). 4/1 Numaralı Ticari Amaçlı Su Ürünleri Avcılığının Düzenlenmesi Hakkında Tebliğ [Notification 4/1 on recreational fisheries.] Gıda, Tarım ve Hayvancılık Bakanlığından. [Ministry of Food, Agriculture and Livestock.] Tebliğ No: 2016/35 [Notification No. 2016/35]

Anonymous (2017). 2017 Su Ürünleri İstatistikleri [Fisheries Statistics in 2017]. https://www.tuik.gov.tr (accessed date: 12 Sept. 2017).

Aydın, İ., Gökçe, G. \& Metin, C. (2008). The effects of netting twine on discard rates of commercial red mullet gillnets in Izmir Bay. Turkish Journal of Fisheries and Aquatic Sciences, 8, 373-376.

Aydın, I. (2011). Is natural bait type a stochastic process for size and condition of fishes in the recreational fishery of Izmir Bay? Mediterranean Marine Science, 12(2), 390-400. DOI: 10.12681/mms.39

Aydın, C. M. \& Bolat, Y. (2014). The selectivity of different hook size in the bottom longline which used for catching white seabream (Diplodus sargus L., 1758) in Finike Bay. Journal of Fisheries Sciences, 8, 186193. DOI: $10.3153 /$ ffscom. 201423

Çekiç, M. \& Başusta, N. (2004). Effect on the species selectivity of different bait and hook size in longline in Iskenderun Bay, Eastern Mediterranean Sea. Ege Journal of Fisheries and Aquatic Sciences, 21, 73-77.

Coelho, R., Santos, M. N. \& Amorim, S. (2012). Effects of hook and bait on targeted and bycatch fishes in an equatorial Atlantic pelagic longline fishery. Bulletin of Marine Science, 88(3), 449-467. DOI: $10.5343 / \mathrm{bms} .2011 .1064$

Dulcic, J. \& Kraljevic, M. (1996). Weight-length relationships for 40 fish species in the eastern Adriatic (Croatian waters). Fisheries Research, 28, 243-251. DOI: 10.1016/0165-7836(96)00513-9

Erdem, M. \& Akyol, O. (2005). A preliminary study on longlining of swordfish (Xiphias gladius L., 1758) in Fethiye Region (Mediterranean). Ege Journal of Fisheries and Aquatic Sciences, 22, 201-204.

\section{CONCLUSION}

This study focused on hook and bait effects on catch composition, size distribution, discard ratio and condition of the captured species in demersal longline fishery on the Turkish coast of the Aegean Sea. Investigated criterions are of crucial importance for fisheries management in terms of providing the sustainability of demersal longline gear which is one of the eco-friendly fishing gears. Therefore, further and comprehensive studies on suitable and sustainable hook-bait combinations are required not only for catching high commercial value fishes and reduction of discards but also for protecting the coastal fish stocks.

\section{ACKNOWLEDGEMENTS}

We would like to thank the Scientific and Technological Research Council of Turkey (TÜBITAK, Project No: 2130269) for its financial support.

FAO (1993). Longline fishing. J.P. George (ed.) Fao training series, no:22 42 pp. FAO Fisheries Department, Rome.

Fernandez-Carvalho, J., Coelho, R., Santos, M.N. \& Amorim, S. (2015). Effects of hook and bait in a tropical northeast Atlantic pelagic long line fishery: part II- target, by-catch, and discard fish. Fisheries Research, 164, 312-321. DOI: 10.1016/j.fishres.2014.11.009

Foster, D.G., Epperly, S.P., Shah, A.K. \& Watson, J.W. (2012). Evaluation of hook and bait type on the catch rates in the western North Atlantic Ocean pelagic longline fishery. Bulletin of Marine Science, 88, 529-545. DOI: $10.5343 / \mathrm{bms} .2011 .1081$

Froese, R. \& Pauly, D. (Ed.) (2018). Fish Base. World Wide Web electronic publication. www.fishbase.org, (06/2018).

Gilman, E., Zollet, E., Beverly, S., Nakano, H., Davis, K., Shiode, D., Dalzell, P. \& Kinan, I. (2006). Reducing sea turtle by-catch in pelagic longline fisheries. Fish and Fisheries, 7(1), 2-23. DOI: 10.1111/j.1467-2979.2006.00196.x

Gilman, E., Clarke, S., Brothers, N., Alfaro-Shigueto, J., Mandelman, J., Mangel, J., Peterson, S., Piovano, S., Thomson, N., Dalzell, P., Donoso, M., Goren, M. \& Werner, T. (2008). Shark interactions in pelagic longline fisheries. Marine Policy, 32(1), 1-18. DOI: 10.1016/j.marpol.2007.05.001

Gökçe, G. \& Metin, C. (2007). Landed and discarded catches from commercial prawn trammel net fishery. Journal of Applied Ichthyology, 23, 543-546. DOI: 10.1111/j.1439-0426.2007.00832.x

Güçlüsoy, H., Öndes, F. \& Tosunoğlu, Z. (2020). The catch characteristics of a set longline fishery in the Foça Special Environmental Protection Area, Turkey. Acta Ichthyology Piscatoria, 50 (3), 247-255.

DOI: 10.3750/AIEP/02809

Gülşahin, A. \& Soykan, O. (2017). Catch composition, length-weight relationship and discard ratios of commercial longline fishery in the Eastern Mediterranean. Cahiers de Biologie Marine, 58, 1-7. DOI: $10.21411 /$ CBM.A.B3268672

Kelleher, K. (2005). Discards in the world's marine fisheries. An update. FAO Fisheries Technical Paper \# 470. FAO: Rome. 131 pp.

Lewison, R.L., Freeman, S.A. \& Crowder, L.B. (2004). Quantifying the effects of fisheries on threatened species: the impact of pelagic longlines on loggerhead and leatherback sea turtles. Ecology Letters, 7(3), 221-231. DOI: 10.1111/j.1461-0248.2004.00573.x

Lilliefors, H.W. (1969). On the Kolmogorov-Smirnov test for the exponential distribution with mean unknown. Journal of the American Statistical Association, 64, 387-389. DOI: 10.1080/01621459.1969.10500983 
Maktay, C.B. (2012). Effect on catching efficency of different natural bait in Longline fisheries. Master's Thesis, Science Institute of Ege University, İzmir, Turkey. 38 pp.

Metin, G., Ilkyaz, A.T., Soykan, O. \& Kınacıgıl, H.T. (2011). Biological characteristics of the common pandora, Pagellus erythrinus (Linnaeus, 1758), in the central Aegean Sea. Turkish Journal of Zoology, 35, 307315. DOI: 10.3906/zoo-0904-4

Moutopoulos, D.K. \& Stergiou, K.I. (2002). Length-weight and length-length relationships of fish species from the Aegean Sea (Greece). Journal of Applied Ichthyology, 18, 200-203. DOI: 10.1046/j.1439-0426.2002.00281.x

Odabaşı, O.B. (2013). Investigation of bycatch composition in longline fisheries in Canakkale Region. Master's Thesis, Science Institute of Onsekiz Mart University, Çanakkale, Turkey.

Özdemir, S., Ayaz, A., Gurbet, R. \& Erdem, Y. (2006). Catch efficiency of bottom long-line used with different hook size and different type bait at dawn and daytime. Anadolu University Journal of Science and Technology, 7, 405-411.

Özgül, A., Ulaş, A., Lök, A., Düzbastılar, F.O. \& Metin, C. (2015). A comparison of alternative circle hook (Kahle Hook) and $\mathrm{J}$ style hook performance in experimental pelagic longline fishery in Turkey. Turkish Journal of Fisheries and Aquatic Sciences, 15, 19-27. DOI : 10.4194/1303-2712-v15_1_03

Özyurt, C. E., Sarıhan, E. \& Akar, M. (2003). The possibilities of using longline at pike-perch (Sander lucioperca, Bogustkaya \& Naseka, 1996) fishing at Seyhan Dam Lake. E.U. Journal of Fisheries \& Aquatic Sciences, 20, 43-50.

R Core Team (2017). R: A Language and Environment for Statistical Computing. R Foundation for Statistical Computing, Vienna, Austria, http://www.R-project.org/

Santos, M.N., Coelho, R., Fernandez-Carvalho, J. \& Amorim, S. (2012). Effects of hook and bait on sea turtle catches in an Equatorial Atlantic pelagic longline fishery. Bulletin of Marine Science, 88(3), 683-701. DOI: $10.5343 / \mathrm{bms} .2011 .1065$
Santos, M.N., Coelho, R., Fernandez-Carvalho, J. \& Amorim, S. (2013). Effects of $17 / 0$ circle hooks and bait on sea turtles bycatch in a Southern Atlantic swordfish longline fishery. Aquatic Conservation: Marine and Freshwater Ecosystems, 23(5), 732-744. DOI: 10.1002/aqc.2324

Sistiaga, M., Herrmann, B., Rindahl, L. \& Tatone, I. (2018). Effect of bait type and bait size on catch efficiency in the European Hake Merluccius merluccius Longline Fishery. Marine and Coastal Fisheries: Dynamics, Management, and Ecosystem Science, 10(1), 12-23. DOI: $10.1002 / \mathrm{mcf} 2.10007$

Soykan, C.U., Moore, J.E., Zydelis, R., Crowder, L. B., Safina, C. \& Lewison, R. L. (2008). Why study bycatch? An introduction to the theme section on fisheries bycatch. Endangered Species Research, 5, 91-102. DOI: 10.3354/esr00175

Soykan, O., Illkyaz, A.T., Metin, G. \& Kınacıgil, H.T. (2015). Growth and reproduction of Boops boops, Dentex macrophthalmus, Diplodus vulgaris, and Pagellus acarne (Actinopterygii: Perciformes: Sparidae) from East-Central Aegean Sea, Turkey. Acta Ichthyologica et Piscatoria, 45(1), 39-55. DOI: 10.3750/AIP2015.45.1.05

Soykan, O., Aydın, İ. \& Kınacıgil, H.T. (2016). A preliminary study on the potential use of an alternative bait for demersal longline fishery; Sepietta sp. Ege Journal of Fisheries and Aquatic Sciences, 33, 163-167. DOI: 10.12714/egejfas.2016.33.2.11

Tesch, F.W. (1971). Age and growth. p. 98-130. In: Methods for assesment of fish production in fresh waters. W.E. Ricker (Ed). Blackwell Scientific Publications, Oxford.

Ulaş, A. \& Düzbastılar, O.F. (2001). Comparison of catch efficiency of different longlines, Ege Journal of Fisheries and Aquatic Sciences, 18, 175-186.

Watson, J.W., Epperly, S.P., Shah, A.K. \& Foster, D.G. (2005). Fishing methods to reduce sea turtle mortality associated with pelagic longlines. Canadian Journal of Fisheries and Aquatic Sciences, 62, 965-981. DOI:10.1139/F05-004. 